\title{
1. An in vitro System Involving Tn3 Transposase that Catalyzes the Formation of DNA Deletions
}

\author{
By Masayuki MoRita and Yoshinobu Sugino \\ Laboratory of Biochemistry, Kansai Medical University, \\ Hirakata, Osaka 573 \\ (Communicated by Motoo KimUrA, M. J. A., Jan. 12, 1989)
}

The prokaryotic transposon Tn3 is known to cause deletion of DNA externally adjacent to its ends. ${ }^{1}{ }^{12}$ ) We have devised a system for quantitative measurement of frequency of such deletions and have shown that their occurrence depends on $\operatorname{tnp} \mathrm{A}$, a gene encoding the transposase, which is known to be essential for transposition, and thus concluded that such deletion may be regarded as intramolecular transposition.3)

Though two in vitro DNA rearrangement systems have thus far been constructed with other transposons ${ }^{4), 5)}$ no such system that is dependent on the $\operatorname{Tn} 3$ transposase has been reported to date. We describe here an in vitro DNA deletion formation system by purified Tn3 transposase.

Materials and methods. Restriction endonucleases and DNA polymerase I were purchased from Takara Shuzo or from Boehringer Mannheim. Tn 3 transposase was prepared as described previously, ${ }^{6}$ ) except that phospho-cellulose chromatography was replaced by Pharmacia FPLC with Mono-S HR 5/5. Integration host factor (IHF) was purified from the overproducer strain K5746 as described by Nash et al..$^{7}$ For some of the later experiments (B-D in Table I), phospho-cellulose fraction was further purified by Phenyl-Sepharose (Pharmacia) chromatography. ${ }^{8)}$ Protein concentrations were determined with the Bio-Rad protein assay kit, with bovine serum albumin (Sigma, Fraction V) as standard.

Plasmid pMM200 was used as the substrate for deletion forming reaction (Fig. 1A). Cells harboring pMM200 are killed at $42^{\circ} \mathrm{C}$, at which temperature the $c \mathrm{I} 857$ repressor is inactivated and transcription from the $p_{\mathrm{L}}$ promoter is derepressed, inducing the kil gene activity. This process is valid unless the kil gene has been inactivated, either directly or indirectly, e.g. by deletion. We have shown that Tn 3 transposase, when supplied in trans by an intact $\operatorname{tn} p \mathrm{~A}$ gene, can cause deletion in pMM200 in vivo. ${ }^{6)}$ Plasmid DNA was purified as described by Maniatis et al. ${ }^{9)}$

Standard in vitro reactions of deletion formation were carried out in a total volume of $20 \mu \mathrm{l}$ which contained $50 \mathrm{mM}$ Tris- $\mathrm{HCl}(\mathrm{pH} \mathrm{7.6}), 10 \mathrm{mM} \mathrm{MgCl}_{2}, 1 \mathrm{mM}$ DTT, $100 \mathrm{mM} \mathrm{KCl}, 50 \mathrm{mM} \mathrm{NaCl}, 10 \%$ glycerin, $2 \mu \mathrm{g}$ pMM200 DNA, 1 to $1.2 \mu \mathrm{g}$ transposase, and 180 to $200 \mathrm{ng}$ IHF. In the earlier stages of this study, DNA polymerase I, ATP and the $4 \mathrm{dNTP}$ (dATP, dGTP, dCTP and dTTP) were included in the reactions. After incubation at $30^{\circ} \mathrm{C}$ for 60 min, reaction mixtures were vortexed with $180 \mu \mathrm{l}$ of $50 \mathrm{mM}$ Tris- $\mathrm{HCl}$ buffer ( $\mathrm{pH} \mathrm{8.8)} \mathrm{containing} 0.22 \%$ sodium dodecyl sulfate, followed by shaking with $200 \mu \mathrm{l}$ of phenol saturated in $20 \mathrm{mM}$ Tris- $\mathrm{HCl}(\mathrm{pH} \mathrm{8.0})$. After centrifugation $(4000 \mathrm{rpm} \times 10 \mathrm{~min})$, the water layer was passed through a Sephadex G100 column $\left(0.2 \mathrm{~cm}^{2} \times 5 \mathrm{~cm}\right)$. The eluent fractions were used for transformation of $\mathrm{C} 600 \mathrm{rec} \mathrm{A}$, which was kindly given by Dr. H. Ogawa. Transformation was carried out as described by Cohen et al.10) 


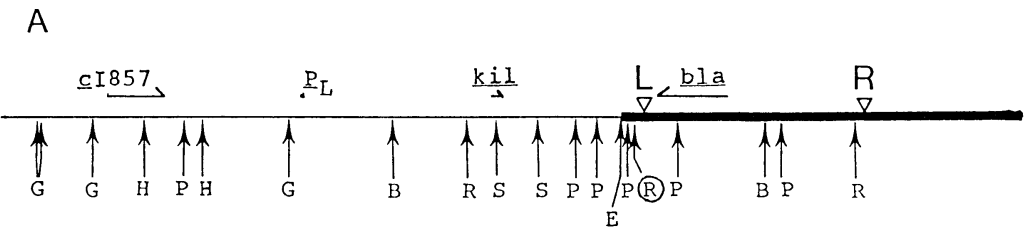

$\mathrm{B}$

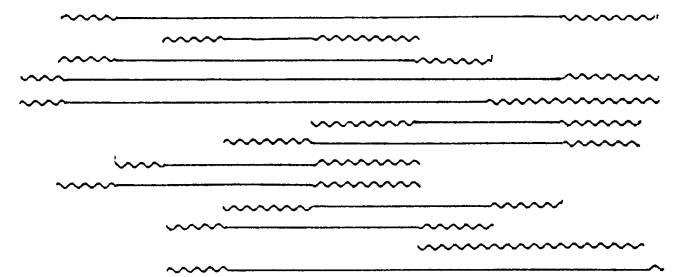

ח

Fig. 1. A : Structure of pMM200. The left end and the right end are connected to form a circle. pMM200 contains a modified Tn3 in which the two inverted repeats (IR) and the bla gene (gene for ampicillin resistance) are intact, but $\operatorname{tn} p \mathrm{~A}$ and $t n p \mathrm{R}$ have been inactivated by deletion. A $\lambda$ DNA fragment including the kil and $c$ I857 genes is also contained in pMM200. Thick line and thin line represent DNA regions derived from $\mathrm{pHK}^{3)}$ and $\lambda c \mathrm{I} 857$, respectively. The horizontal arrows above indicate the direction of transcription of each gene. Left(L) and right $(\mathrm{R})$ inverted repeats of Tn3 are represented by triangles. Restriction sites are abbreviated as follows; E, EcoRI; R, EcoRV; B, BamHI; G, BglII ; S, SalI; P, PstI; H, HindIII. The EcoRV site marked by the circle was retained in all the in vitro products examined (see Results section). B: Regions deleted in in vitro reaction products. Horizontal lines indicate the DNA regions whose absence could be shown by restriction analysis, and wavy lines indicate the regions within which the deletion end points must be located.

except for differences in temperatures. Transformants were selected on L-agar ${ }^{\overline{3}}$ containing $100 \mu \mathrm{g} / \mathrm{ml}$ ampicillin $(\mathrm{Ap})$. The deletion forming activity was estimated by the ratio of the number of Ap resistant transformants at $42^{\circ} \mathrm{C}$ to that at $30^{\circ} \mathrm{C}$.

Results. The results of in vitro deletion forming reactions are shown in Table I. The activity was dependent on the Tn 3 transposase, IHF and $\mathrm{Mg}^{++}$. Since DNA polymerase I was known to be required for replication of ColE1-type plasmids, ${ }^{11)}$ (and our substrate pMM200 belongs to this group), we initially included this enzyme, (and ATP and the $4 \mathrm{dNTP}$ ) in the reaction mixture. But removal of DNA polymerase I had no significant effect (B, C), or it even seemed to be inhibitory at times (D). Furthermore, the activity did not depend on ATP or 4 dNTP (D). The reaction products, after having been isolated from transformants, were examined by restriction analysis. Most of the plasmids examined (33 of 46) were shorter than pMM200 as shown by agarose gel electrophoresis and therefore must be deletion products. All the products examined (46) were found to retain the $E c o \mathrm{RV}$ site which is present between the kil gene and Tn3 left IR (see Fig. 1A); thus none of these deletions starts exactly from the end of Tn3. Thirteen deletion products were analyzed further by other restriction enzymes (Fig. 1B). Although all the plasmids examined had lost DNA regions including the kil gene or the $p_{\mathrm{L}}$ promoter, starting points of the deletions were heterogeneous on both sides. 
Table I. DNA deletion formation in vitro

\begin{tabular}{|c|c|c|c|c|c|}
\hline \multicolumn{6}{|c|}{ A. Effect of IHF and transposase } \\
\hline \multirow{2}{*}{$\begin{array}{l}\text { Transposase } \\
\quad(\mu \mathrm{g} / \mathrm{ml})\end{array}$} & \multirow{2}{*}{$\begin{array}{l}\text { IHF } \\
(\mu \mathrm{g} / \mathrm{ml})\end{array}$} & Transformants & \multirow{2}{*}{\multicolumn{3}{|c|}{$\begin{array}{l}\text { Ratio of transformants } \\
\left(42^{\circ} \mathrm{C} / 30^{\circ} \mathrm{C}\right) \times 10^{5}\end{array}$}} \\
\hline & & $30^{\circ} \mathrm{C} \times 10^{-4} \quad 42^{\circ} \mathrm{C}$ & & & \\
\hline $\begin{array}{l}0 \\
0 \\
2.5 \\
2.5 \\
10 \\
10 \\
50 \\
50\end{array}$ & $\begin{array}{l}0 \\
9 \\
0 \\
9 \\
0 \\
9 \\
0 \\
9\end{array}$ & $\begin{array}{l}4.3 \\
3.1 \\
4.8 \\
5.5 \\
6.3 \\
3.8 \\
6.7 \\
7.8\end{array}$ & \multicolumn{3}{|c|}{$\begin{array}{r}4.7 \\
9.7 \\
6.3 \\
7.3 \\
<1.6 \\
2.6 \\
6.0 \\
23.1\end{array}$} \\
\hline \multicolumn{6}{|c|}{ B. Effect of IHF and DNA polymerase I } \\
\hline \multirow{2}{*}{$\begin{array}{l}\text { Transposase } \\
(\mu \mathrm{g} / \mathrm{ml})\end{array}$} & \multirow{2}{*}{$\begin{array}{c}\mathrm{IHF} \\
(\mu \mathrm{g} / \mathrm{ml})\end{array}$} & \multirow{2}{*}{$\begin{array}{l}\text { DNA poly- } \\
\text { merase I } \\
\text { (units) }\end{array}$} & Transformants & \multirow{2}{*}{\multicolumn{2}{|c|}{$\begin{array}{l}\text { Ratio of transformants } \\
\qquad\left(42^{\circ} \mathrm{C} / 30^{\circ} \mathrm{C}\right) \times 10^{5}\end{array}$}} \\
\hline & & & $30^{\circ} \mathrm{C} \times 10^{-4} \quad 42^{\circ} \mathrm{C}$ & & \\
\hline $\mathrm{B} 1, \mathrm{~B} 2$ & & & $\mathrm{~B} 1, \mathrm{~B} 2 \mathrm{~B} 1, \mathrm{~B} 2$ & $\mathrm{~B} 1$, & $\mathrm{B} 2$ \\
\hline $\begin{array}{rr}50, & 60 \\
50, & 60 \\
0, & 0 \\
50, & 60\end{array}$ & $\begin{array}{r}10 \\
0 \\
10 \\
10\end{array}$ & $\begin{array}{l}0 \\
0.5 \\
0.5 \\
0.5\end{array}$ & 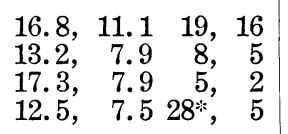 & $\begin{array}{r}11.3 \\
6.1 \\
2.9 \\
22.4\end{array}$ & $\begin{array}{r}14.4 \\
6.3 \\
2.5 \\
6.7\end{array}$ \\
\hline
\end{tabular}

C. Effect of IHF in the absence of DNA polymerase I

\begin{tabular}{c|c|ccc|cc}
\hline \multirow{2}{*}{$\begin{array}{c}\text { Transposase } \\
(\mu \mathrm{g} / \mathrm{ml})\end{array}$} & $\begin{array}{c}\text { IHF } \\
(\mu \mathrm{g} / \mathrm{ml})\end{array}$ & \multicolumn{2}{|c|}{ Transformants } & \multicolumn{2}{c}{$\begin{array}{c}\text { Ratio of transformants } \\
\left(42^{\circ} \mathrm{C} / 30^{\circ} \mathrm{C}\right) \times 10^{5}\end{array}$} \\
\cline { 3 - 7 } & & $30^{\circ} \mathrm{C} \times 10^{-4}$ & $42^{\circ} \mathrm{C}$ & $\mathrm{C} 1, \quad \mathrm{C} 2$ & Average \\
60 & & $\mathrm{C} 1, \mathrm{C} 2$ & $\mathrm{C} 1, \mathrm{C} 2$ & 9.1, & 6.5 & 7.8 \\
0 & 0 & $5.5,4.6$ & 5,3 & $1,6,2.6$ & 2.2 \\
60 & 10 & $6.4,3.9$ & 1,1 & 1.6 & 2.9 \\
\hline
\end{tabular}

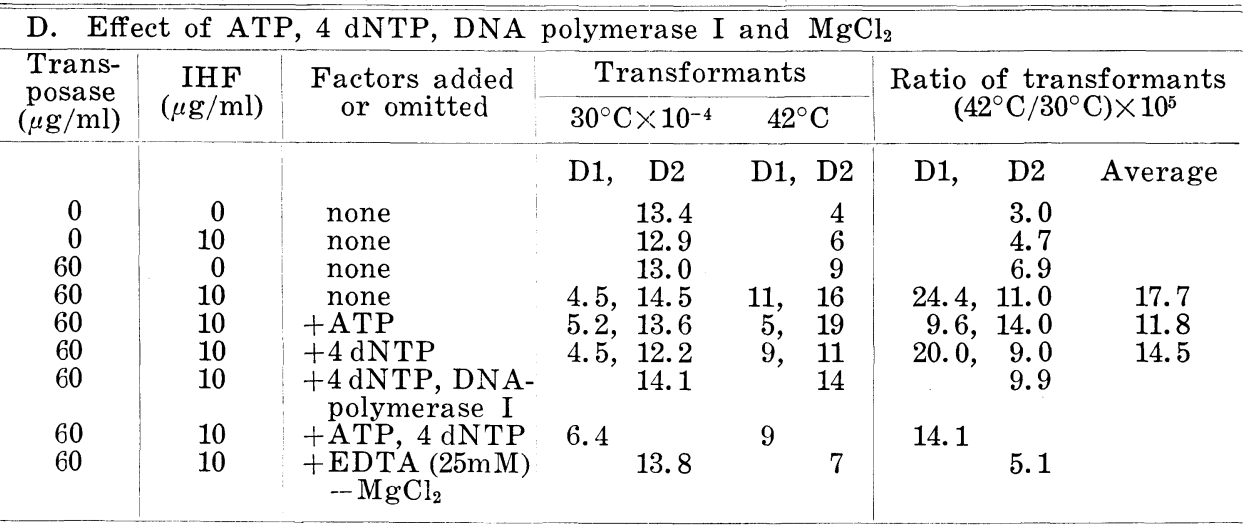

Five hundred nanograms of DNA was used for each transformation assay. A small volume of transformed cell cultures was plated at $30^{\circ} \mathrm{C}$. The rest of the cells was collected by centrifugation and similarly plated at $42^{\circ} \mathrm{C}$. Values of the transformants at $42^{\circ} \mathrm{C}$ are the actual number of colonies. Transformants for equivalent volume were calculated for $30^{\circ} \mathrm{C}$. Transformation with substrate DNA with no incubation gave an average of $(4.99 \pm 0.79) \times 10^{-5}$ for the ratio of the transformants at $42^{\circ} \mathrm{C}$ to that at $30^{\circ} \mathrm{C}$. DNA polymerase I $(0.5$ units) was included in all reactions in $A$ and, when indicated, in B and D. ATP $(2 \mathrm{mM})$ and the $4 \mathrm{dNTP},(75 \mu \mathrm{M}$ each) were included in all reactions in $\mathrm{A}, \mathrm{B}$, and $\mathrm{C}$ and the indicated samples in $\mathrm{D}$. Results of two separate reactions are shown in B, C, and D. Results shown in D2 are the sum of two separate transformation assays of a single reaction. Plasmids from all of the Ap and temperature resistant transformants indicated by * in A and B1 were purified and used for restriction pattern analysis shown in Fig. 1. 
Discussion. The only biological activity reported thus far for purified Tn 3 transposase is the DNA binding activity. ${ }^{(6), 11), 12)}$ Our finding in the present study that purified transposase mediates DNA deletion formation is the first report that describes an enzymatic activity of this protein. While transposase-dependent deletions, which may be regarded as intramolecular transposition, ${ }^{3)}$ have been shown to occur invariably from one of the ends of Tnз in vivo,1),2),6) in our in vitro reaction no product molecules with deletions starting exactly at an end of Tn 3 have so far been observed. This discrepancy between the in vivo and in vitro systems cannot be explained at the present stage. Possibilities are that more protein component (s) and/or different reaction conditions are required for the specificity. However, that the in vitro reaction requires IHF, which is involved in another transposon-related DNA rearrangement ${ }^{5}$ ) or a transposase-DNA interaction, ${ }^{13)}$ suggests that our in vitro system reflects at least some aspects of the in vivo process.

Acknowledgments. Dr. Harvey I. Miller kindly gave us the IHF overproducer strain K5746. This work was supported by Grants-in-Aid for Scientific Research from the Ministry of Education, Science and Culture of Japan.

\section{References}

1) Nisen, P. D. et al. (1977): J. Mol. Biol., 117, 975-998.

2) Ohtsubo, H., Ohmori, H., and Ohtsubo, E. (1979): Cold Spring Harbor Symp. Quant. Biol., 43, 1269-1277.

3) Sugino, Y., and Kawashima, H. (1983) : Jpn. J. Genet., 58, 79-93.

4) Mizuuchi, K. (1983) : Cell, 35, 785-794.

5) Morisato, D., and Kleckner, N. (1987): ibid., 51, 101-111.

6) Morita, M., Tsunasawa, S., and Sugino, Y. (1987): J. Biochem., 101, 1253-1264.

7) Nash, H. A. et al. (1987): J. Bacteriol., 169, 4124-4127.

8) Nash, H. A., and Robertson, C. A. (1981): J. Biol. Chem., 256, 9246-9253.

9) Maniatis, T., Fristch, E. F., and Sambrook, J. (1982): Molecular Cloning. A Laboratory Manual. Cold Spring Harbor Laboratory, New York, pp. 86-96, 366-367.

10) Cohen, S. N., Chang, A. C. Y., and Hsu, L. (1972) : Proc. Natl. Acad. Sci. U.S.A., 69, 2110-2114.

11) Grindley, N. D. F., and Kelley, W. S. (1976) : Molec. Gen. Genet., 143, 311-318.

12) Fennewald, M. A. et al. (1981): J. Biol. Chem., 256, 4687-4690.

13) Ichikawa, H. et al. (1987) : Proc. Natl. Acad. Sci. U.S.A., 84, 8220-8224.

14) Wiater, L. A., and Grindley, N. D. F. (1988): EMBO J., 7, 1907-1911. 